Article

\title{
Synthesis of ZSM-5 monoliths with hierarchical porosity through a steam-assisted crystallization method using sponges as scaffolds
}

\author{
Tiejing Hu, Jian Liu, Changyan Cao *, Weiguo Song\# \\ Beijing National Laboratory for Molecular Sciences, Laboratory for Molecular Nanostructures and Nanotechnology, Institute of Chemistry, Chinese \\ Academy of Sciences, Beijing 100190, China \\ University of Chinese Academy of Sciences, Beijing 100049, China
}

\section{A R T I C L E I N F}

\section{Article history:}

Received 24 February 2017

Accepted 27 March 2017

Published 5 May 2017

\section{Keywords:}

Hierarchically porous structure

Zeolite

Steam-assisted crystallization

Acidity

\begin{abstract}
A B S T R A C T
Self-supporting ZSM-5 crystals with hierarchical porosity were prepared through a steam-assisted crystallization method using sponges as rigid scaffolds. The synthesized materials were characterized by X-ray diffraction, nitrogen sorption, scanning electron microscopy, transmission electron microscopy, solid-state nuclear magnetic resonance spectroscopy and ammonia temperature-programmed desorption. The ZSM-5 monoliths exhibited high crystallinities, hierarchical porous structures and strong acidities. They showed superior catalytic performance in the liquid-phase esterification reaction between benzyl alcohol and hexanoic acid.
\end{abstract}

(C) 2017, Dalian Institute of Chemical Physics, Chinese Academy of Sciences. Published by Elsevier B.V. All rights reserved.

\section{Introduction}

Hierarchically structured porous materials have triggered extensive research because of their fascinating features such as high surface areas, interface-facilitated transport and advanced mass transport kinetics [1-3]. Recently, there have been successful attempts to synthesize hierarchically porous zeolites. For example, post-synthesis treatments can be used to generate hierarchically porous zeolites through selective leaching of aluminum (dealumination) or silicon (desilication) from the zeolite framework $[4,5]$. The major disadvantage of such a process is the partial degradation of the crystalline nature of the zeolite, and consequently, a reduction in the catalytic activity. More recently, other processes to create zeolites with a hierarchical porosity using a hard sacrificial templates have also been examined; carbon materials [6-8], mesoporous silica spheres
$[9,10]$ and aerogels $[11,12]$ have been investigated. However, these processes were somewhat expensive and time consuming. Cationic polymers have also been successfully employed to produce hierarchical zeolites $[13,14]$, but the synthetic zeolites were not suitable for industrial catalysis.

In the case of industrial catalysis, a certain amount of binders, such as alumina, silica or clay, is generally used for cementing zeolite crystals into large sticks or granules that are mechanically stable. However, the inorganic binders may dilute the active zeolite and partially block the pore system, which results in diffusion limitations and inaccessibility of the active species [15]. To overcome these problems, continuous progress has been made on the development of mechanically stable zeolite monoliths with uniform shapes and hierarchical structures. Such monolithic zeolite materials facilitate the diffusion of the reactants and products as well as the reaction efficiency and

\footnotetext{
* Corresponding author. Tel/Fax: +86-10-62557908; E-mail: cycao@iccas.ac.cn

\# Corresponding author. Tel/Fax: +86-10-62557908; E-mail: wsong@iccas.ac.cn

This work was supported by the National Natural Science Foundation of China (21333009) and the Youth Innovation Promotion Association of CAS (2017049).

DOI: 10.1016/S1872-2067(17)62828-6 | http://www.sciencedirect.com/science/journal/18722067 | Chin. J. Catal., Vol. 38, No. 5, May 2017
} 
can be used in practical application. For example, Shi et al. $[16,17]$ have reported the preparation of HSZs by using ordinary mesoporogens such as triethanolamine (TEA), P123, F127 and even sucrose as in situ carbonaceous templates. Ryoo et al. [18] designed several bifunctional templates, combing the features of both structural guide agent (SDA) and mesoporogens within one molecule, and successfully synthesized zeolite nanosheets with hierarchical structures. However, the reported synthesis of the hierarchically structured zeolites by massive mesoporogens was neither cost efficient nor friendly because most of the template agents were difficult to make and nocuous. Novel synthesis routes using few mesoporogens are highly desirable and have become a promising research field.

In this study, we prepared high-quality zeolite monoliths with hierarchical porosity through a steam-assisted crystallization (SAC) method using sponges as rigid scaffolds. X-ray diffraction (XRD) and nuclear magnetic resonance (NMR) spectroscopy analysis showed the ZSM-5 monoliths were highly crystalline. Because of their hierarchical porous structure, the zeolite monoliths had a higher surface area, stronger acidity, and showed better catalytic activity than that of traditional ZSM-5 in the liquid phase esterification reaction.

\section{Experimental}

\subsection{Reagents}

Tetraethylorthosilicate (TEOS, $98 \mathrm{wt} \%$ ), tetrapropylammoniumhydroxide (TPAOH, $25 \mathrm{wt} \%)$, hexanoic acid (98.8\%), benzyl alcohol (98.8\%), ammonium nitrate (98.5\%), toluene (99.5\%), 4-methylbenzyl alcohol (98\%), 4-nitrobenzyl alcohol (98\%), 4-methoxybenzyl alcohol (98\%) and 3-phenylpropan-1-ol were purchased from J\&K Corporation. Aluminum isopropoxide (AIP, 97\%) was obtained from Beijing Chemical Reagent Corporation (Beijing, China). Aqueous ammonia solution $\left(28 \%\right.$ in $\left.\mathrm{H}_{2} \mathrm{O}\right)$, sodium hydroxide and ethanol (99.9\%) were purchased from Beijing Chemical Company. All the reagents were used without further purification. Nanosponges were purchased from Henan.

\subsection{Preparation of zeolite monoliths}

The sponges were cut into small cubes that were suitable for the size of the autoclave. To synthesize M-ZSM-60 (M indicates monolith, ZSM represents ZSM-5 zeolite, 60 represents the synthesized materials with $\mathrm{Si} / \mathrm{Al}$ molar ratio of 60 ), $0.275 \mathrm{~g}$ of AIP was dissolved in $16 \mathrm{~mL}$ of ethanol at room temperature for $2 \mathrm{~h}$ and then added to $14 \mathrm{~g}$ of TEOS. The solution was stirred for $5 \mathrm{~h}$ and then the sponge was immersed in the solution. The impregnated sponge was then placed into a Teflon-lined autoclave containing $2 \mathrm{~mL}$ of $30 \%$ aqueous ammonia solution. The autoclave was then closed and treated at $80{ }^{\circ} \mathrm{C}$ for $12 \mathrm{~h}$ in a hot air oven. The autoclave was then quenched to room temperature and the sponge was once again impregnated with the ethanol solution containing AIP and TEOS. This procedure was repeated three times to ensure efficient loading of the silica source and aluminum source into the sponge. The finally load- ed sponge was adsorbed with appropriate quantity of TPAOH. The TPAOH/Si molar ratio was maintained as 0.27 . The dried sponge containing silica, aluminum and TPAOH was placed inside a Teflon-lined autoclave containing $2 \mathrm{~mL}$ of distilled water for steam-assisted crystallization. The autoclave was closed and placed in a hot air oven at $130^{\circ} \mathrm{C}$ for $36 \mathrm{~h}$. After the crystallization period, the autoclave was taken out and quenched to room temperature. The product was collected, dried at $80{ }^{\circ} \mathrm{C}$ for $8 \mathrm{~h}$ and then calcined at $550{ }^{\circ} \mathrm{C}$ for $8 \mathrm{~h}$ in air to remove the TPAOH and the sponge. The synthesis of M-ZSM-40 and M-ZSM-90 with different Si/Al ratios were similarly conducted by accordingly changing the AIP content in the precursor solution while keeping the addition of TEOS constant. For comparison, traditional ZSM-5 (denoted as ZSM-5(60)) was synthesis with a molar ratio of $28 \mathrm{Na}_{2} \mathrm{O}: 1 \mathrm{Al}_{2} \mathrm{O}_{3}: 120 \mathrm{SiO}_{2}: 4000 \mathrm{H}_{2} \mathrm{O}$.

\subsection{Catalysis conditions}

Prior to the catalytic tests, all the materials were exchanged to the $\mathrm{H}$-form with an aqueous solution of $\mathrm{NH}_{4} \mathrm{NO}_{3}(1.0 \mathrm{~mol} / \mathrm{L})$ at $90{ }^{\circ} \mathrm{C}$ for $4 \mathrm{~h}$ and then converted to the $\mathrm{H}^{+}$form through calcination at $550{ }^{\circ} \mathrm{C}$ for $5 \mathrm{~h}$. Esterification of the alcohol with an acid was carried out in a double-necked round bottom flask fitted with a reflux condenser. The alcohol (15 mmol), acid (18 mmol) and toluene $(15 \mathrm{~mL})$ were added to the round bottom flask, as well as $n$-nonane, which is an internal standard. The solution was heated to $110{ }^{\circ} \mathrm{C}$ using a silicone oil bath and then $250 \mathrm{mg}$ of the catalyst was added. The reaction mixture was stirred using a magnetic stirrer and the stirring speed was maintained at $1200 \mathrm{r} / \mathrm{min}$ to avoid external mass transfer limitations. The reaction products were analyzed by GC (Agilent $6890 \mathrm{~N}$ ) with a capillary column (DB-5, $30.0 \mathrm{~m} \times 320 \mathrm{~mm} \times$ $0.25 \mathrm{~mm}$ ) and FID, and the products were further identified by GC-MS (Shimadzu, GCMS-QP 2010S) with a capillary column (DB-5 ms, $30.0 \mathrm{~m} \times 320 \mathrm{~mm} \times 0.25 \mathrm{~mm}$ ).

\subsection{Characterization}

The morphology and size of the resultant powders were characterized with a field emission scanning electron microscope (FESEM JEOL-6701F). Transmission electron microscopy (TEM) images were taken using a JEM-2100F (JEOL) operated at $100 \mathrm{kV}$. Power XRD patterns were collected on a Rigaku- 2500 in the $2 \theta$ range of $5^{\circ}-55^{\circ}$. The relative crystallinity (RC) of the synthesized M-ZSMs was calculated from the ratio of the sum of the intensities of the four most intense reflections in the $2 \theta$ range of $22.5^{\circ}-24^{\circ}$ and the corresponding sum of the parent ZSM-5, which was purchased from the Catalyst Plant of Nankai University. $\mathrm{N}_{2}$ adsorption isotherms were measured at $-196{ }^{\circ} \mathrm{C}$ on a Quantachrome Autosorb AS-1 instrument; the samples were outgassed at $120{ }^{\circ} \mathrm{C}$ for $12 \mathrm{~h}$ prior to testing. Pore size distributions were evaluated from the adsorption isotherms using the Barret-Joyner-Halenda (BJH) formula and the microporous volume was evaluated by nonlocal density functional theory. ${ }^{27} \mathrm{Al}$ and ${ }^{29} \mathrm{Si}$ solid-state NMR spectroscopy experiments were performed on an AVANCE III 400WB spectrometer. The spectra were collected at a frequen- 
cy of $104.1 \mathrm{MHz}$ (0.4 s recycle delay time) for ${ }^{27} \mathrm{Al}-\mathrm{NMR}$ and at a frequency of $79.3 \mathrm{MHz}$ (2 s recycle delay time) for ${ }^{29} \mathrm{Si}-\mathrm{NMR}$. Compressive strength tests were conducted in an Instron5567. $\mathrm{SiO}_{2} / \mathrm{Al}_{2} \mathrm{O}_{3}$ molar ratios were analyzed by XRF. Thermogravimetric measurements were performed on a Netzsch STA 494C Jupiter TG/DSC instrument. Ammonia temperature-programmed desorption ( $\mathrm{NH}_{3}$-TPD) was conducted using a Micromeritics Autochem 2920 instrument. The catalyst $(0.15$ g) was charged in a U-shaped quartz cell and pretreated in $\mathrm{Ar}$ $(20 \mathrm{~mL} / \mathrm{min})$ at $500{ }^{\circ} \mathrm{C}$ for $1 \mathrm{~h}\left(\right.$ ramp rate $\left.10{ }^{\circ} \mathrm{C} / \mathrm{min}\right)$ then cooled to $100{ }^{\circ} \mathrm{C}$. The gas flow was then changed to a mixture of $10 \% \mathrm{NH}_{3}-90 \% \operatorname{Ar}(40 \mathrm{~mL} / \mathrm{min})$ for $2 \mathrm{~h}$. The sample was then purged with $\operatorname{Ar}(20 \mathrm{~mL} / \mathrm{min})$ at $100{ }^{\circ} \mathrm{C}$ for $2 \mathrm{~h}$ to remove free and weakly adsorbed ammonia. The $\mathrm{NH}_{3}$-TPD profile was measured by rising the temperature up to $600^{\circ} \mathrm{C}$ (ramp rate 10 ${ }^{\circ} \mathrm{C} / \mathrm{min}$ ) using a TCD detector.

\section{Results and discussion}

Scheme 1 illustrates the synthesis of M-ZSM monolith through the SAC method with a sponge as a rigid scaffold. First, TEOS (silicon source) and AIP (aluminum source) were dispersed in ethanol to form aluminosilicate seeds, which were then adsorbed by the PUF sponge. The sponge was then treated under hydrothermal conditions in an autoclave using the SAC method with ammonium hydroxide as steam. The same process was repeated three times to load more seeds, ensuring the mechanical stability of the final monolithic product. Second, the sponge obtained in the first step was impregnated in TPAOH solution to adsorb an appropriate quantity of the template and then crystallized under hydrothermal conditions in an autoclave through the SAC method with $\mathrm{H}_{2} \mathrm{O}$ as steam. Finally, the M-ZSM monolith was obtained after calcination at $550{ }^{\circ} \mathrm{C}$ to remove the sponge and the TPAOH template. As shown in the photos (Scheme 1), the zeolite monolith maintained the shape of the original sponge template after the sequential treatments. Depending on the exact conditions, $0.1 \mathrm{~g}$ of the nanosponge

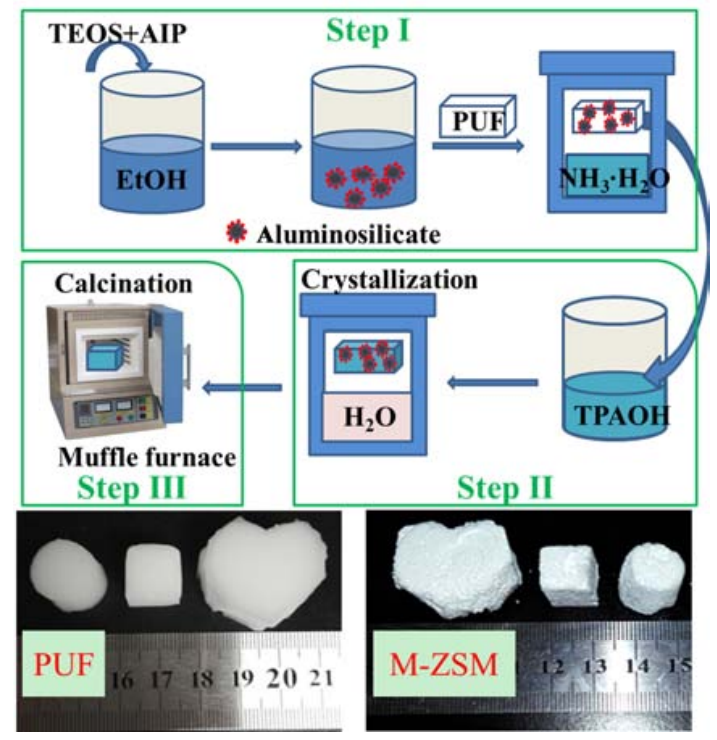

Scheme 1. Schematic illustration for the synthesis of the M-ZSMs monoliths. template produced approximately $2 \mathrm{~g}$ of zeolite, indicating a high yield based on the proposed synthetic strategy. Because the sponge scaffolds are easy to handle, M-ZSMs monoliths with different shapes and sizes can be produced, which would facilitate their potential applications.

The strong Brönsted acidity of ZSM-5 zeolite originates from the heterogeneous substitution of $\mathrm{Al}^{3+}$ with $\mathrm{Si}^{4+}$ in the framework. However, because of the difference in the chemical valence and ionic radius between $\mathrm{Al}$ and $\mathrm{Si}$, such a substitution is limited [19]. Here, to extend the range of the hierarchical zeolites with variable Si/Al ratios and surface acidity, and consequently, to satisfy the requirements for diverse catalytic applications, M-ZSMs with varied Si/Al ratios from 40 to 90 were prepared under identical conditions at a fixed TPAOH/Si ratio of 0.25 (Table 1, entries 1, 2 and 3). The syntheses of M-ZSMs with different $\mathrm{Si} / \mathrm{Al}$ ratios were conducted by changing the AIP content in the precursor solution and keeping the amount of TEOS constant.

The microstructure of the obtained M-ZSM-60 monolith was characterized by SEM and TEM. As shown in Fig. 1(a), the sponge scaffold had an interconnecting macroporous structure. The obtained M-ZSM-60 monolith was composed of many dense blocks, among which macropores were formed (Fig. 1(b)). The high-magnification SEM image showed that the zeolite consisted of many close-packed particles (Fig. 1(c)). The TEM image further confirmed that the monolithic zeolite consisted of intergrown particles with a globular morphology (Fig. 1(d)). The corresponding SAED pattern demonstrated the good crystallinity of the zeolite (inset in Fig. 1(d)). The elemental mapping images of M-ZSM-60 showed that the Si and Al were uniformly dispersed in the M-ZSM-60.

Fig. 2(a) shows the corresponding XRD patterns of the M-ZSMs with different Si/Al ratios and traditional ZSM-5 for comparison. All diffraction peaks could be indexed to the standard ZSM-5. No other peaks were observed, indicating the purity of the obtained M-ZSMs. Moreover, depending on the $\mathrm{Al}$ doping content, the calculated RC increased from $88 \%$ for sample M-ZSM-40 to $98 \%$ for sample M-ZSM-90 (Table 1). This result suggested that the increase of $\mathrm{Al}$ content in M-ZSMs is unfavorable for the crystallization transformation during SAC treatment.

The obtained M-ZSMs were further characterized by NMR spectroscopy to confirm the structure of the zeolite framework. As shown in Fig. 2(b), the ${ }^{29} \mathrm{Si}$ MAS-NMR spectra clearly showed one major band with a chemical shift at $-112 \mathrm{ppm}$ corresponding to $\mathrm{Si}(\mathrm{OSi})_{4}\left(\mathrm{Q}_{4}\right)$, which suggested that most of the silicon atoms were located in $\mathrm{Q}_{4}$ sites, as expected for a silicate

Table 1

Textural parameters, composition, and RC of all the synthesized materials.

\begin{tabular}{lccccccc}
\hline Entry & Sample & Si/Al & $\begin{array}{c}\text { Reaction } \\
\text { time } \\
(\mathrm{h})\end{array}$ & $\begin{array}{c}\text { Reaction } \\
\text { temperature } \\
\left({ }^{\circ} \mathrm{C}\right)\end{array}$ & $\begin{array}{c}S_{\text {BET }} \\
\left(\mathrm{m}^{2} / \mathrm{g}\right)\end{array}$ & $\begin{array}{c}V_{\text {pore }} \\
\left(\mathrm{cm}^{3} / \mathrm{g}\right)\end{array}$ & $\begin{array}{c}\mathrm{RC} \\
(\%)\end{array}$ \\
\hline 1 & M-ZSM-40 & 42 & 36 & 130 & 452 & 0.62 & 88 \\
2 & M-ZSM-60 & 64 & 36 & 130 & 440 & 0.43 & 94 \\
3 & M-ZSM-90 & 91 & 36 & 130 & 463 & 0.29 & 98 \\
4 & ZSM-5(60) & 63 & 36 & 130 & 432 & 0.22 & 92 \\
\hline
\end{tabular}




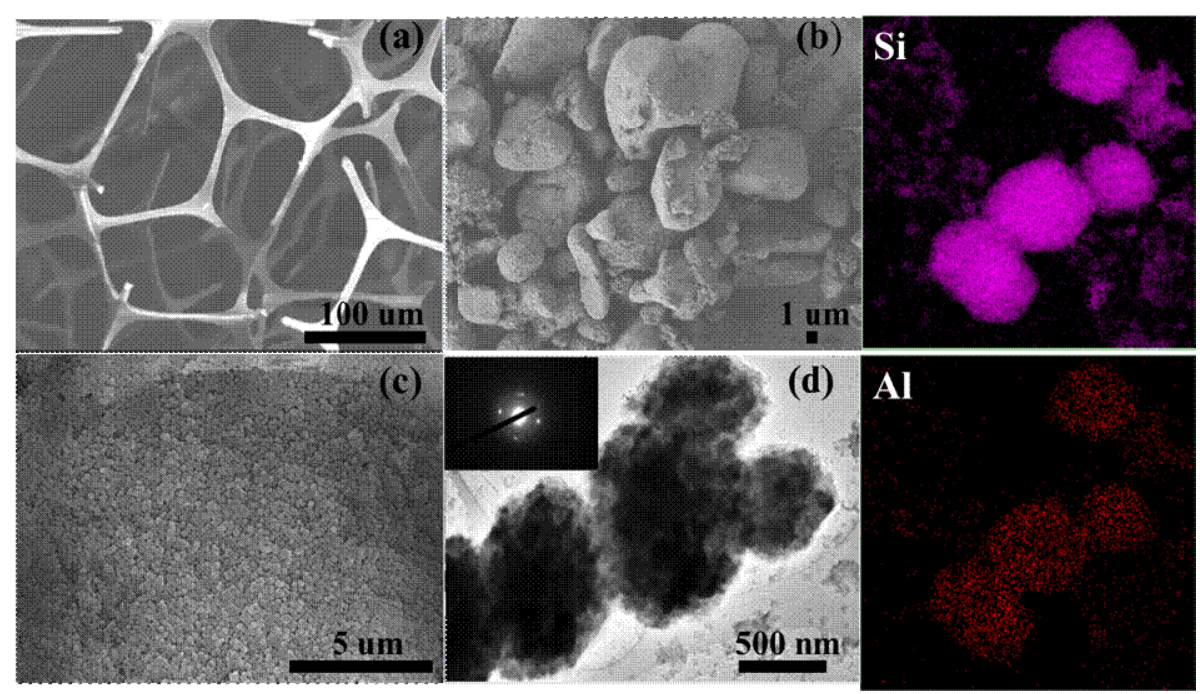

Fig. 1. SEM images of (a) the original sponge and (b, c) M-ZSM-60, TEM image of (d) M-ZSM-60 (Top right and bottom right: the corresponding SAED pattern).
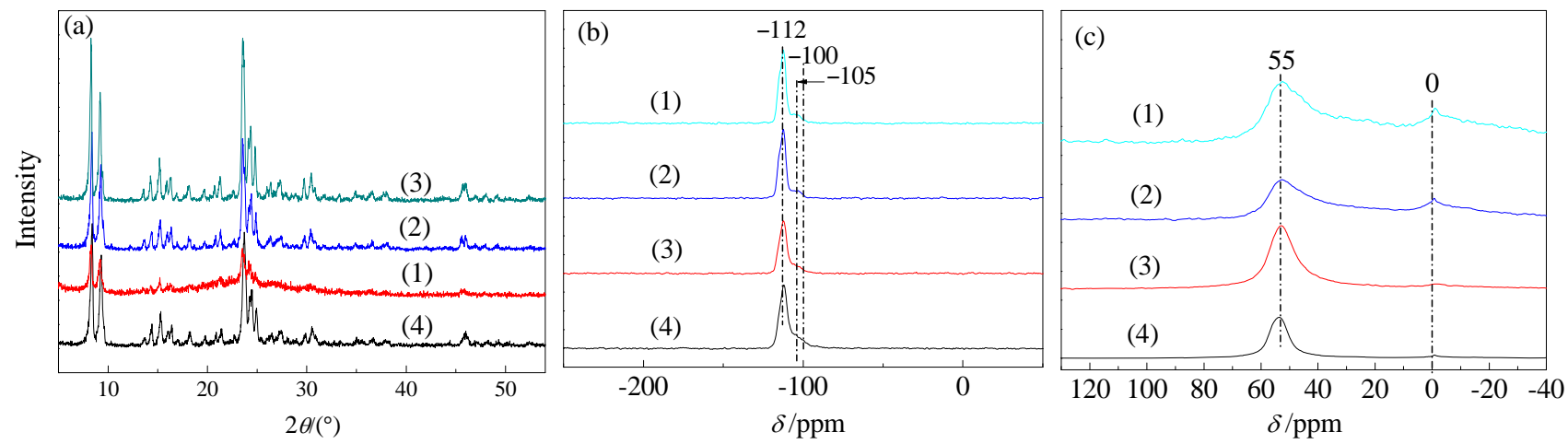

Fig. 2. (a) XRD patterns, (b) ${ }^{29} \mathrm{Si}$ and (c) ${ }^{27} \mathrm{Al}$ NMR MAS spectra of the M-ZSMs and ZSM-5(60). (1) M-ZSM-40; (2) M-ZSM-60; (3) MZSM-90; (4) ZSM-5(60).

framework. The shoulder peak at $-100 \mathrm{ppm}$ was ascribed to (HO)Si(OSi) $)_{3}\left(\mathrm{Q}_{3}\right)$, also implying that the MFI zeolite was highly crystalline. Furthermore, another weak shoulder peak at -105 ppm was ascribed to (AlO)-Si(OSi) $)_{3}$, suggesting the existence of some amorphous silicate species in the monolithic zeolites. The ${ }^{27} \mathrm{Al}$ MAS-NMR spectra (Fig. 2(c)) exhibited two peaks at $\sim 55$ ppm and 0 ppm. The peak at $\sim 55$ ppm was ascribed to aluminum species with tetrahedral coordination. The peak with a lower intensity at $\sim 0 \mathrm{ppm}$ was assigned to the octahedral $\mathrm{Al}$ in the form of polymeric oxo-hydroxo-Al-cations and extra-framework $\mathrm{Al}$ species or the framework $\mathrm{Al}$ species located at the defect sites.

Nitrogen adsorption-desorption experiments were carried out to determine the textural porosity of the obtained M-ZSMs monoliths (Fig. 3). The isotherm of ZSM-5(60) exhibited a typical type-I profile with a high uptake at low relative pressures $\left(p / p_{0}<0.1\right)$ and a plateau at high relative pressures $\left(0.4<p / p_{0}\right.$ $<1.0$ ), indicating that the resultant materials had a purely microporous phase with negligible mesoporosity. For M-ZSM-90, a similar type-I isotherm was observed. However, for M-ZSM-40 and M-ZSM-60, typical type-IV isotherms with obvious hysteresis loops and apparent uptakes at high relative pressures were observed, demonstrating the existence of both microporosity and mesoporosity. The corresponding surface areas and pore volumes are listed in Table 1.

Fig. 4(a) presents the $\mathrm{NH}_{3}$-TPD profiles for ZSM-5(60) and the M-ZSMs. The density of the surface acid sites increased in the order ZSM-5(60) < M-ZSM-90 < M-ZSM-40 < M-ZSM-60. There were two $\mathrm{NH}_{3}$ desorption peaks for ZSM-5(60) and the

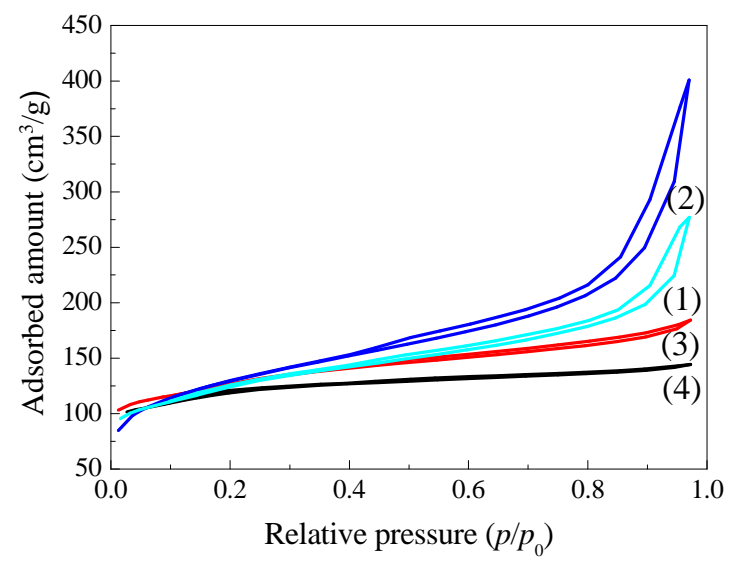

Fig. 3. $\mathrm{N}_{2}$ adsorption-desorption isotherms of the M-ZSMs and ZSM-5(60). (1) M-ZSM-40; (2) M-ZSM-60; (3) M-ZSM-90; (4) ZSM-5(60). 

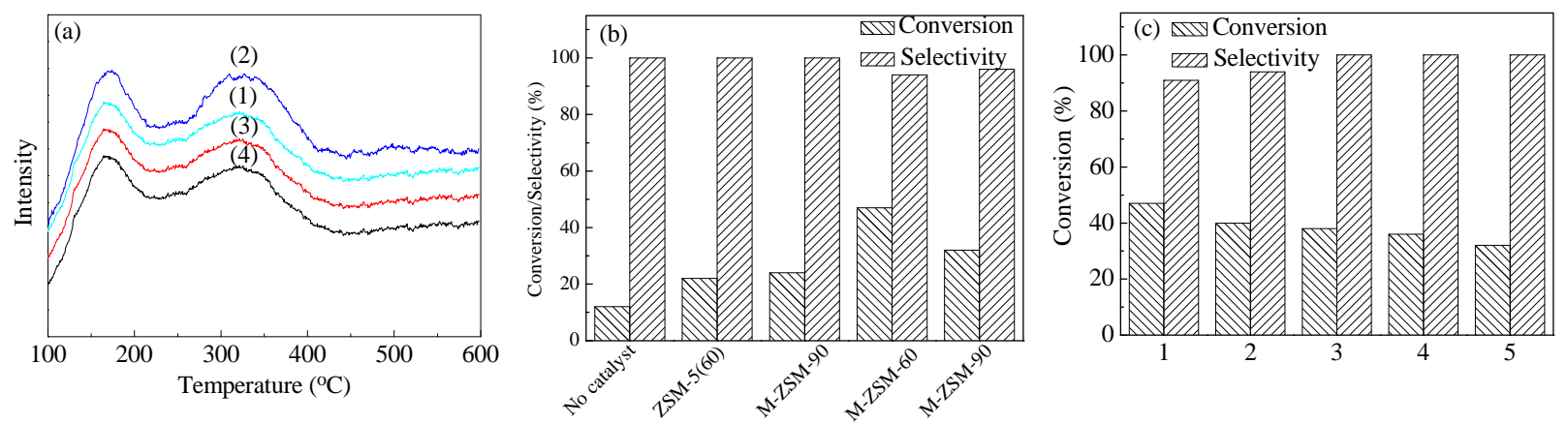

Fig. 4. (a) $\mathrm{NH}_{3}$-TPD curves of (1) M-ZSM-40, (2) M-ZSM-60, (3) M-ZSM-90, (4) ZSM-5(60) and ZSM-5(60); (b) Catalytic conversion and selectivity of the M-ZSMs and ZSM-5(60) catalysts in the esterification reaction between benzyl alcohol and hexanoic acid; (c) Recycling of the M-ZSM-60 catalyst in the esterification reaction between benzyl alcohol and hexanoic acid.

M-ZSMs, which were attributed to weak and strong acidic sites. Generally, the peak at a higher temperature is related to a strong acid site, which was attributed to the Al-OH-Si bridge in the 10-member ring (10 MR) of ZSM-5. The peak at a lower temperature was attributed to a weak or medium strength acid site, which was associated with the nonframework Al atoms and zeolite defects. The peaks for the M-ZSMs were stronger than those for ZSM-5(60), indicating that the acidity of the M-ZSMs was higher than that of ZSM-5(60). It was unusual that M-ZSM-60 had a higher acid density than M-ZSM-40. It is likely that the method used in this work does not allow high aluminum content into the MFI framework. As shown in Fig. 2(c), there was a significant amount of extra-framework Al species on M-ZSM-40, indicating that less $\mathrm{Al}$ atoms were incorporated into the framework.

The liquid-phase esterification reaction between benzyl alcohol and hexanoic acid was then employed as a probe reaction to examine the catalytic performance of the M-ZSMs and ZSM-5(60). The M-ZSMs exhibited higher conversions of benzyl alcohol than ZSM-5(60) (Fig. 4(b)). The esterification reaction involves large molecular species, which is mainly catalyzed by

Table 2

The esterification reaction with different alcohols and hexanoic acid using M-ZSM-60 as a catalyst.

(2)

Brönsted acids located at the surface of the mesoporous walls [20]. Thus, the low conversion of ZSM-5(60) could be attributed to diffusion limitations owing to its small pore diameter. The high catalytic activities of M-ZSM-60 and M-ZSM-40 indicated that hierarchical frameworks can lead to easier access to the active sites for reactants and faster diffusion of products. These results were consistent with the $\mathrm{NH}_{3}$ - $\mathrm{TPD}$ results.

Hierarchically structured zeolites can be used in many other catalytic reactions involving large molecules, in which diffusion constraints and/or the adsorption of the reactant molecules onto the acid sites are the main concern. Various esterification reactions of alcohols and acids could also be catalyzed with high yields (Table 2), indicating the superior efficiency of the M-ZSMs catalyst. The reactants containing an electron-donating group $\left(\mathrm{MeO}^{-}\right)$showed a higher reactivity relative to those containing electron withdrawing groups $\left(\mathrm{NO}_{2}{ }^{-}\right.$; Table 2 , entries 3 and 4). Furthermore, the M-ZSM-60 catalyst showed good recyclability (Fig. 4(c)).

\section{Conclusions}

ZSM-5 monoliths with hierarchical porous structures were prepared through a steam-assisted crystallization method using sponges as rigid scaffolds. The obtained ZSM-5 monoliths were characterized by XRD and NMR. The ZSM- 5 monoliths were highly crystalline. Owing to their hierarchical porous structure, they had strong acidity and exhibited superior catalytic performance in the liquid-phase esterification reaction.

\section{References}

[1] M. E. Davis, Nature, 2002, 417, 813-821.

[2] Y. Guo, Y. Jin, H. Wu, L. Zhou, Q. Chen, X. Zhang, X. Li, Int. J. Hydrogen Energy, 2014, 39, 21044-21052.

[3] S. Lopez-Orozco, A. Inayat, A. Schwab, T. Selvam, W. Schwieger, Adv. Mater., 2011, 23, 2602-2615.

[4] S. Abello, A. Bonilla, J. Perez-Ramirez, Appl. Catal. A, 2009, 364, 191-198.

[5] D. Verboekend, J. Perez-Ramirez, Chem. Eur. J., 2011, 17, 1137-1147.

[6] H. Katsuki, S. Furuta, T. Watari, S. Komarneni, Microporous Mesoporous Mater., 2005, 86, 145-151.

[7] C. Madsen, C. J. H. Jacobsen, Chem. Commun., 1999, 8, 673-674. 


\section{Graphical Abstract}

Chin. J. Catal., 2017, 38: 872-878 doi: 10.1016/S1872-2067(17)62828-6

Synthesis of ZSM-5 monoliths with hierarchical porosity through a steam-assisted crystallization method using sponges as scaffolds

Tiejing Hu, Jian Liu, Changyan Cao *, Weiguo Song*

Institue of Chemistry, Chinese Academy of Sciences; University of Chinese Academy of Sciences

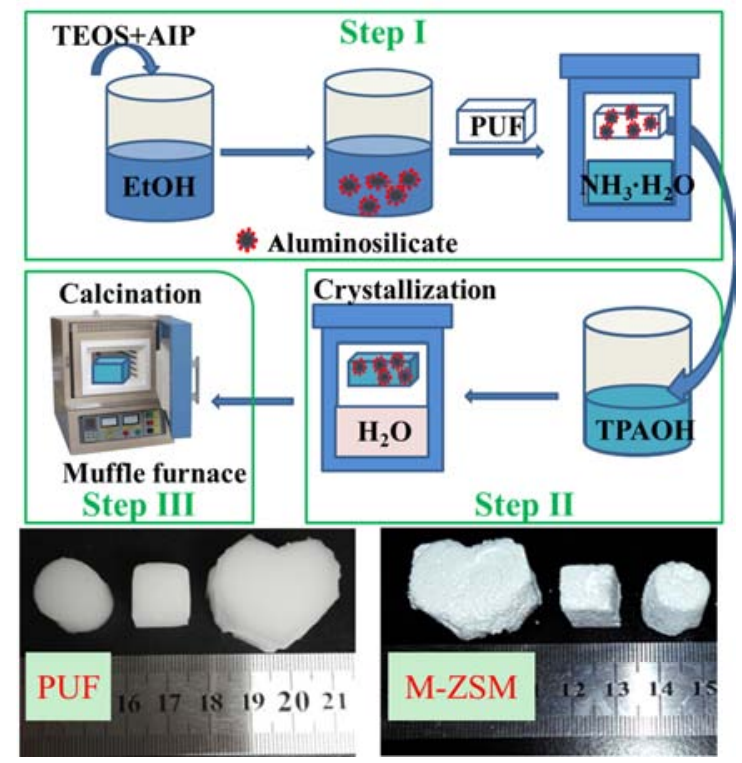

Self-supporting ZSM-5 crystals with hierarchical porosity were prepared through a steam-assisted crystallization method using sponges as rigid scaffolds. The synthesized ZSM-5 monoliths exhibited high crystallinity, hierarchical porous structures and strong acidities.

[8] Y. S. Tao, H. Kanoh, K. Kaneko, J. Phys. Chem. B, 2003, 107, 10974-10976.

[9] A. G. Dong, N. Ren, W. L. Yang, Y. J. Wang, Y. H. Zhang, D. J. Wang, J. H. Hu, Z. Gao, Y. Tang, Adv. Funct. Mater., 2003, 13, 943-948.

[10] Z. D. Wang, Y. M. Liu, J. G. Jiang, M. Y. He, P. Wu, J. Mater. Chem., 2010, 20, 10193-10199.

[11] Y. M. Fang, H. Q. Hu, G. H. Chen, Microporous Mesoporous Mater., 2008, 113, 481-489.

[12] Y. S. Tao, H. Kanoh, K. Kaneko, J. Am. Chem. Soc., 2003, 125, 6044-6045.

[13] H. Wang, T. J. Pinnavaia, Angew. Chem. Int. Ed., 2006, 45, 7603-7606.

[14] F. S. Xiao, L. F. Wang, C. Y. Yin, K. F. Lin, Y. Di, J. X. Li, R. R. Xu, D. S.
Su, R. Schlogl, T. Yokoi, T. Tatsumi, Angew. Chem. Int. Ed., 2006, 45, 3090-3093.

[15] S. Mitchell, N. L. Michels, K. Kunze, J. Perez-Ramirez, Nat. Chem., 2012, 4, 825-831.

[16] J. Zhou, Z. L. Hua, J. L. Shi, Q. J. He, L. M. Guo, M. L. Ruan, Chem. Eur. J., 2009, 15, 12949-12954.

[17] J. A. Zhou, Z. L. Hua, Z. C. Liu, W. Wu, Y. Zhu, J. L. Shi, ACS Catal,, 2011, 1, 287-291.

[18] M. Choi, K. Na, J. Kim, Y. Sakamoto, O. Terasaki, R. Ryoo, Nature, 2009, 461, 246-249.

[19] http://www.iza-structure.org/databases/.

[20] V. N. Shetti, J. Kim, R. Ryoo, J. Mater. Chem., 2012, 22, 4637-4640.

\section{蒸汽辅助结晶法合成多级孔整体型ZSM-5分子篮 \\ 胡铁靖, 刘 剑, 曹昌燕”, 宋卫国 ${ }^{*}$ \\ 中国科学院化学研究所, 分子纳米结构与纳米技术院重点实验室, 北京100190 \\ 中国科学院大学, 北京100049}

摘要: 多级孔分子笁由于其高的比表面积、良好的传质性能和可调控的孔径等特性, 引起了广大科研工作者的研究兴趣. 近年来, 通过选择性脱除骨架硅或铝, 成功合成了多级孔沸石分子篮材料. 但是由于骨架原子的脱除使分子篮的结晶度降 低, 进而使其催化效率降低. 通过硬模板法(如炭黑、介孔硅球、气凝胶等), 也用于合成多级孔沸石分子筛. 然而, 这种方法 制备过程较为复杂, 且成本较高. 因此, 亟需发展新的多级孔分子笁的制备方法.

此外, 在工业应用中, 沸石分子篮催化剂通常需要做成整体柱状或片形以消除固定床反应器的床层压降. 合成整体型 沸石分子篮的传统方法是在沸石分子篮成型过程中添加 $\mathrm{SiO}_{2}$ 和 $\mathrm{Al}_{2} \mathrm{O}_{3}$ 等无机粘结剂. 虽然该方法简单易行, 但沸石分子篎 
的孔道结构容易被破坏, 而且无机粘结剂的存在使分子筛活性中心的密度减少. 为了解决这些问题, 合成整体型多级孔沸 石分子篮, 不仅具有较强的机械稳定性, 适应于工业, 而且其多级孔道有利于分子的扩散, 从而具有较高的催化活性.

针对上述问题, 我们以海绵作为模板, 通过蒸汽辅助结晶(steam-assisted crystallization, SAC)方法, 制备具有多级孔道 的整体型ZSM-5分子篮. 通过X射线衍射 $\mathrm{XRD}$ )、氮吸附脱附、扫描电子显微镜(SEM)、透射电子显微镜(TEM)、固态核磁 共振和氨气的程序升温脱附 $\left(\mathrm{NH}_{3}-\mathrm{TPD}\right)$ 等手段对分子篎进行了结构与性质表征.

XRD和固态核磁共振的结果表明, 成功合成了不同Si/Al的ZSM-5分子篮. SEM和TEM结果进一步确定了合成的整体 型多级孔ZSM-5分子篎(记作M-ZSM-n, n代表Si/Al的摩尔比), 由于分子笁颗粒的堆积形成的介孔, 海绵模板提供的固体骨 架形成的大孔, 分子篮本身的微孔, 共同构成了微孔-介孔-大孔的整体型ZSM-5分子篮. 透射电子显微镜上配备的X射线能 谱仪(EDS)结果表明, 分子篮中的 Si和Al元素能够均匀的分布. 氮吸附脱附证明所得整体型分子篎具有明显的介孔结构. $\mathrm{NH}_{3}$-TPD结果表明, 不同Si/Al的整体型多级孔ZSM-5分子篮具有不同强度的酸性, 其酸性强度: ZSM-5(60) $<\mathrm{M}-\mathrm{ZSM}-90<$ M-ZSM-40 < M-ZSM-60. 苯甲醇和己酸的液相反应进一步验证了这一结论, 而且合成的整体型多级孔ZSM-5分子篮比传 统的ZSM-5分子笁(记作ZSM-5(60))表现出更优异的催化活性.

关键词: 多级孔道结构; 分子篮; 蒸汽辅助结晶; 酸性

收稿日期: 2017-02-24. 接受日期: 2017-03-27. 出版日期: 2017-05-05.

*通讯联系人. 电话/传真: (010)62557908; 电子信箱: cycao@iccas.ac.cn

\#通讯联系人. 电话/传真: (010)62557908; 电子信箱: wsong@iccas.ac.cn

基金来源: 国家自然科学基金(21333009); 中国科学院青年创新促进会(2017049).

本文的英文电子版由Elsevier出版社在ScienceDirect上出版(http://www.sciencedirect.com/science/journal/18722067). 